quills curved inwards, broadly obtuse. Tail longish, nearly even, the feathers rather broad, truncated and rounded.

Bill bluish-black at the tip, blue towards the base; cere and margin yellow. Iris hazel. Feet gamboge-yellow; claws brownish-black. The general colour of the upper parts is dark umber; the forehead with a slight margin of whitish, the quills blackish-brown, the tail with three bands of dark brown, alternating with two whitish bands, and a narrower terminal band of greyish, the tips white. Throat whitish; cheeks reddish-brown, with a dark brown mustăchial band; the under parts generally light reddish, marked with guttiform umber spots along the neck, and sagittiform larger spots of the same colour on the breast and sides. Tibial feathers of the same colour, with numerous smaller spots.

Length 14 inches; extent of wings 32 ; bill $\frac{11}{12}$ along the ridge, $1 \frac{1}{4}$ along the gap.

\title{
Adult Female.
}

Colouring generally similar to that of the male, lighter above, more tinged with red beneath, where the spots are larger and more irregular.

Length 16 inches; extent of wings 35 ; bill 1 along the ridge, $1 \frac{1}{4}$ along the gap.

\section{R OU G H - L E G GED B U Z Z A R D.}

†Buteo lagopus, Gmel.

\section{PLATE XI.}

The Red-legged Hawk seldom goes farther south along our Atlantic coast than the eastern portions of North Carolina, nor have I ever seen it to the west of the Alleghanies. It is a sluggish bird, and confines itself to the meadows and low grounds bordering the rivers and salt-marshes, along our bays and inlets. In such places you may see it perched on a stake, where it remains for hours at a time, unless some wounded bird comes in sight, when it sails after it, and secures it without manifesting much swiftness of flight. It feeds principally on moles, mice, and other small quadrupeds, and never attacks a duck on the wing, although now and then it pursues a wounded one. When not alarmed, it usually flies low and sedately, and does not exhibit any of the courage and vigour so conspicuous in most other hawks, suffering 



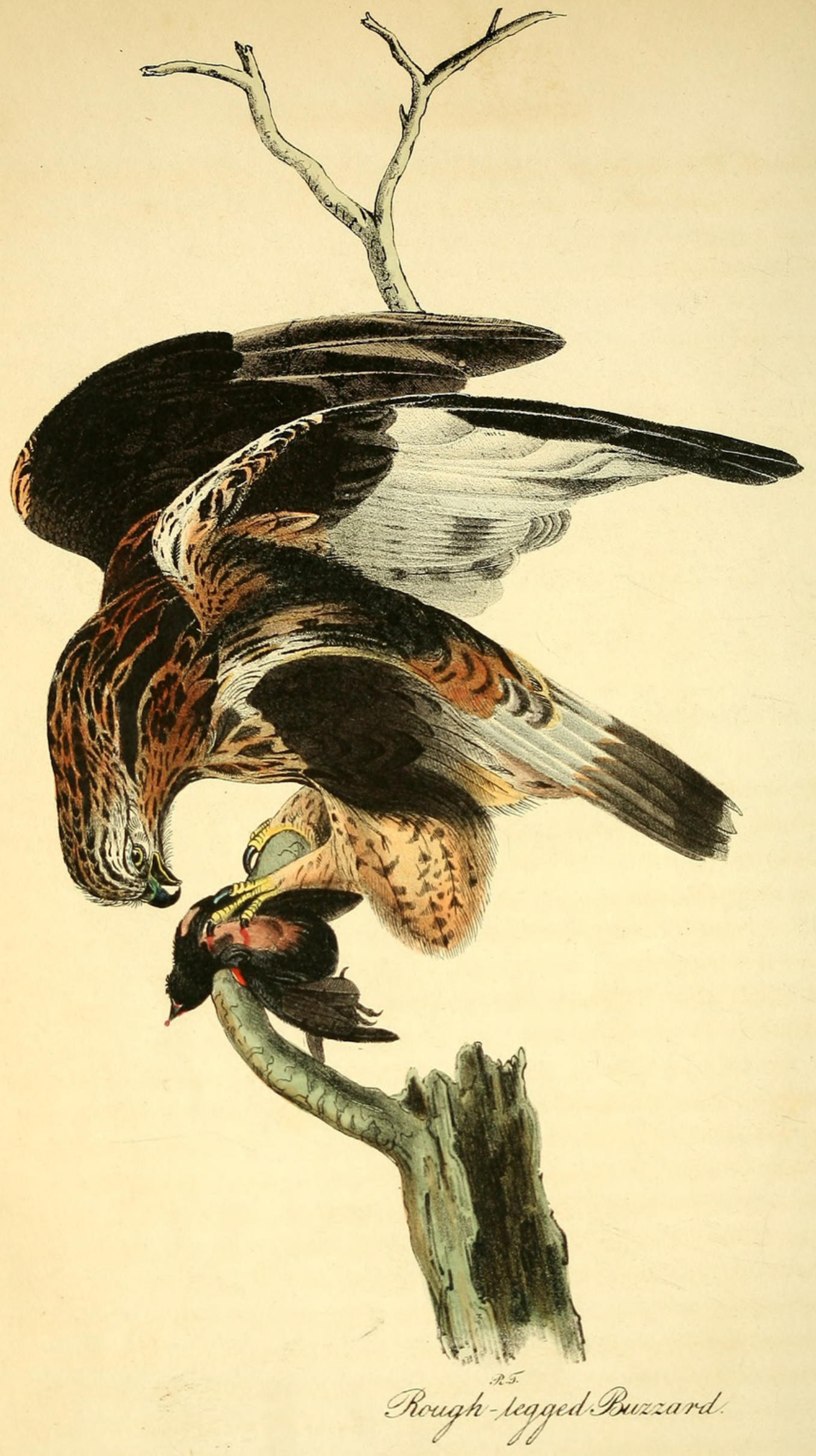


thousands of birds to pass without pursuing them. The greatest feat I have seen them perform was scrambling at the edge of the water, to secure a lethargic frog.

They alight on trees to roost, but appear so hungry or indolent at all times, that they seldom retire to rest until after dusk. Their large eyes indeed seem to indicate their possession of the faculty of seeing at that late hour. I have frequently put up one, that seemed watching for food at the edge of a ditch, long after sunset. Whenever an opportunity offers, they eat to excess, and, like the Turkey Buzzards and Carrion Crows, disgorge their food, to enable them to fly off. The species is more nocturnal in its habits than any other Hawk found in the United States.

M. Tемminck says that this species frequents the north of Europe in autumn and winter, and it is at times seen in Holland. My friend $\mathrm{Mr}$. YARRELL states, that, "although it has now been killed once or oftener in almost every county in England, it has rarely been known to breed there, and is usually obtained in the spring or autumn, when changing its latitude from south to north, or vice versa."

The number of meadow mice which this species destroys ought, one might think, to ensure it the protection of every husbandman; but so far is this from being the case, that in America it is shot on all occasions, simply because its presence frightens Mallards and other Ducks, which would alight on the ponds, along the shores of which the wily gunner is concealed; and in England it is caught in traps as well as shot, perhaps for no better reason than because it is a Hawk. But so scarce is it in the latter country, that I never could procure one in the flesh there.

My friend Mr. Swainson considered our bird in its immature plumage, in which he has figured it in the Fauna Boreali-Americana, as the true Falco lagopus; and Dr. Richardson, in the same work, speaks of it as follows:"A specimen of this bird, in most perfect plumage, was killed in the month of September, by Mr. Drummond, on the Smoking River, one of the upper branches of the Peace River. It arrives in the Fur Countries in April or May, and, having reared its young, retires southward early in October. It winters on the banks of the Delaware and Schuylkill, returning to the north in the spring. It is by no means an uncommon bird in the districts through which the expedition travelled, but, being very shy, only one specimen was procured. A pair were seen at their nest, built of sticks, on a lofty tree, standing on a low, moist, alluvial point of land, almost encircled by a bend of the Saskatchewan. They sailed round the spot in a wide circle, occasionally settling on the top of a tree, but were too wary to allow us to come within gun-shot; so that, after spending much time in vain, we were fain to relinquish the chase. In the softness and fulness of its plumage, its feathered 
legs, and habits, this bird bears some resemblance to the Owls. It flies slowly, sits for a long time on the bough of a tree watching for mice, frogs, \&c., and is often seen skimming over swampy pieces of ground, and hunting for its prey by the subdued daylight, which illuminates even the midnight hours in the high parallels of latitude."

Nothing is known respecting their propagation in the United States, and I must pass over this subject. They leave us in the beginning of March, and betake themselves to more northern countries; yet not one did either myself, or my youthful and enterprising party, observe on my late rambles in Labrador.

Black Hawk, Falco niger, Wils. Amer. Orn., vol. vi. p. 82. Adult.

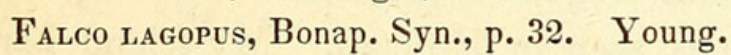

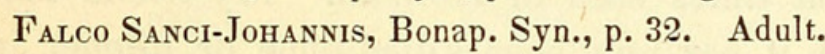

Buteo lagopus, Rough-legged Buzzard, Swains. \& Rich., F. Bor. Amer., vol. ii. p. 52.

Rough-LegGed F Flcon, Falco lagopus, Wils. Amer. Orn., vol. iv. p. 59, Young; vol. v. p. 216, Adult and Young.

\section{Middle-aged Male.}

Wings long, third quill longest, fourth almost equal, second shorter than fifth, first very short; first four abruptly cut out towards the end on the inner web; secondaries broad and rounded. Tail rather long, broad, rounded.

Bill dull bluish-grey, black at the end. Iris hazel, projecting part of the eyebrow greenish-blue, cere yellow. Toes yellow, claws black. Bases of the black bristles of the lore whitish. The head and neck are streaked with umber-brown and yellowish-white, the centre and tip of each feather being of the former colour. Back umber-brown, variegated with light reddishbrown and yellowish-white. Quills dark brown towards the end, the outer webs of the first six tinged with grey, the base of all white, that colour extending farther on the secondaries, of most of which, and of some of the primaries, the inner web is irregularly barred with brown. Upper tailcoverts white, irregularly barred with dark brown. Tail white at the base, brown and mottled towards the end, with a broad subterminal band of brownish-black, the tips brownish-white. Middle and hind part of the thorax, with the sides, blackish-brown. Breast yellowish-white, largely spotted and blotched with umber. Feathers of the legs paler yellowish-red, barred with dusky; abdomen yellowish-white, as are the under tail-coverts, which are marked with a small brown spot.

Length 22 inches; extent of wings 4 feet 1 inch; bill along the back $1 \frac{5}{8}$, along the edge $1 \frac{7}{12}$; tarsus $2 \frac{11}{12}$.

The Female agrees in colouring, but is considerably larger. 
The old bird, which has a very different look as to colour, has been noticed or described under different names.

Black Hawk, Falco niger, Wils. Amer. Orn., vol. vi. p. 82, pl. liii. fig. 1.

Falco Sancti-Johannis, Bonap. Synops. of Birds of the United States, p. 32.

The bill, feet, and iris are coloured as in middle age; but the plumage is of a nearly uniform chocolate-brown, the bases of the quills, however, remaining white, the broad band on the under surface of the wing being the same as in the younger bird; and the tail being brown, without a subterminal bar of black, but slightly tipped with brownish-white, and barred with yellowishwhite on the inner webs, the bars becoming more distinct on the outer feathers. The wings in both reach to near the tip of the tail. The feathers on the nape of the neck are white, excepting at the extremities, which is also the case in the young and middle aged birds, and is not a circumstance peculiar to this species, being observed in $F$. Albicilla, F.palumbarius, $F$. Nisus, and many others.

\section{Genus III.-AQUila, Briss. EAGLE.}

Bill rather short, deep, compressed; upper mandible with the dorsal outline nearly straight and sloping at the base, beyond the cere decurved, the sides sloping and slightly convex, the edges nearly straight, with a slight convexity and a shallow sinus close to the strong subtrigonal tip; lower mandible with the dorsal outline convex, the tip obliquely truncate. Head large, roundish, flattened above. Nostrils oval, oblique, nearer the ridge than the margin. Neck rather short. Body very large. Feet rather short, very robust; tarsi roundish, feathered to the toes, which are rather short, united at the base by short webs, covered above with a series of angular scales, and towards the end with a few large scutella; claws long, curved, rounded, flat beneath, acuminate. Plumage compact, imbricated, glossy; feathers of the head and neck narrow and pointed; space between the bill and eye covered with small bristle-pointed feathers, disposed in a radiating manner. Wings long, the fourth quill longest; the first short; the outer six abruptly cut out on the inner web. Tail rather long, ample, rounded. 


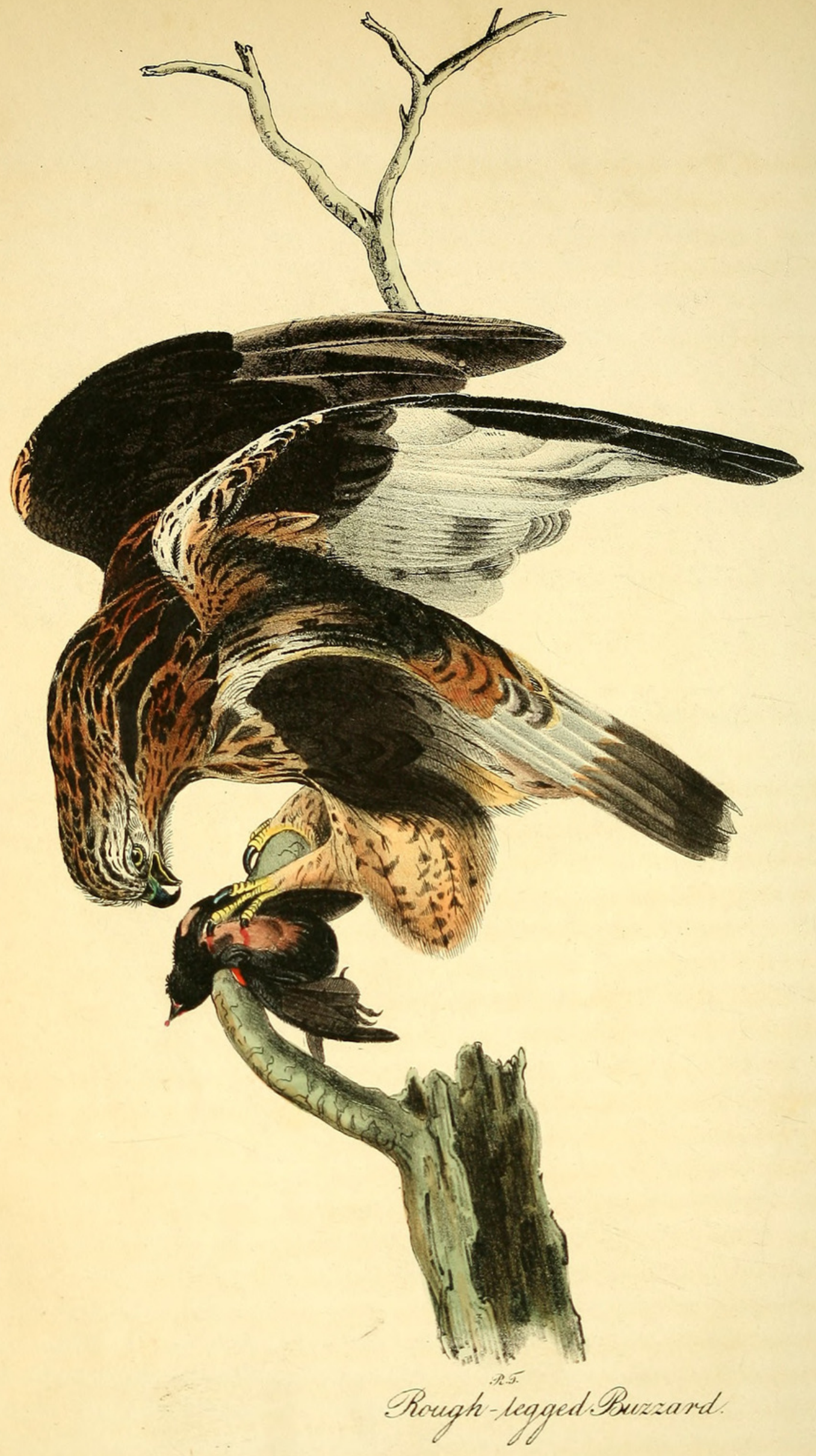




\section{$2 \mathrm{BHL}$ Biodiversity Heritage Library}

Audubon, John James. 1840. "Rough-legged Buzzard, Buteo lagopus, Gmel. [PI. 11]." The birds of America : from drawings made in the United States and their territories 1, 46-49. https://doi.org/10.5962/p.319124.

View This Item Online: https://www.biodiversitylibrary.org/item/124833

DOI: https://doi.org/10.5962/p.319124

Permalink: https://www.biodiversitylibrary.org/partpdf/319124

\section{Holding Institution}

Smithsonian Libraries

\section{Sponsored by}

Biodiversity Heritage Library

\section{Copyright \& Reuse}

Copyright Status: NOT_IN_COPYRIGHT

This document was created from content at the Biodiversity Heritage Library, the world's largest open access digital library for biodiversity literature and archives. Visit BHL at https://www.biodiversitylibrary.org. 